\title{
COMPETENCE OF OLDER EMPLOYEES
}

\author{
Gabriela-Maria MAN* \\ mangabrielamaria@yahoo.com \\ Mihaela MAN** \\ mihaela.man@ulbsibiu.ro \\ * "Dimitrie CANTEMIR” UNIVERSITY BUCURESTI, RoMANIA \\ ** "LUCIAN BLAGA” UNIVERSITY SIBIU, ROMANIA
}

\begin{abstract}
Across the world, the number of old adults has grown significantly over recent decades. This has raised a number of questions related to the availability of human resources in the present day. One current concern, visible in society, is related to older employees' competence and performance. Often, older employees are perceived as less competent and perceived that they perform less well than younger employees, but this image does not meet the reality. Studies related to older employees' performance show that certain aspects of performance are either equal to, slightly lower, or even higher than those of younger employees. Important elements that make the performance of older adults comparable with the performance of younger adults, among others, include experience, and level of past and present cognitive and physical stimulation; elements with very large interpersonal variability.
\end{abstract}

\section{KEYWORDS:}

Competence, old employees, cognitive abilities, performance

\section{Introduction}

What happens in organizations is a reflection of what happens in a wider context, the social context. Therefore, a deeper analysis of the organizational context cannot be done without mentioning the social dynamics. One major change, at social level, is related to the demographic side. When it comes to the present day, it is noticeable that life expectancy and longevity have increased greatly (United Nations, 2013; Kontis et al., 2017). For instance, life expectancy in Europe is 80.7 years for women and 73.7 years for men; in North America it is 81.5 years for women and
76.8 years for men (United Nations, 2017a). In the last decade, global life expectancy has increased 3.6 years (United Nations, 2017b). The increase in longevity is also reflected in the higher number of old adults alive today, and in a higher number in the future. For example, today, the number of old adults over 60, in Europe, is 183.0 million but in the 2050 the number will be approximately 247.2 million (United Nations, 2017a). But the large number of old adults is not balanced by a large number of young people. For instance, in Europe, the proportion of people over 60 is $25 \%$, while that of the children (0-14 years) is just $16 \%$, and the 
proportion of the adolescents and young adults between 15-24 years is only $11 \%$ (United Nations, 2017b). This means that a large proportion of employees both today and in the future might be older.

\section{Competence and performance of old employees}

The present social context creates the opportunity to ask questions about the competence or performance of older employees. It seems that concerns about the capabilities and competence of older adults are raised in different contexts and in different cultures (Gordon \& Arvey, 2004; Age UK, 2005;Abrams, Vauclair \& Swift, 2011). One in three Britons doubt that old adults, after the age of 70 , are capable and competent individuals (Age UK, 2005). According to Posthuma and Campion (2009) it cannot be said that older employees are less competent, overall, than young people. A meta-analysis carried out on 96 studies on the relationship between performance and age, revealed that these two variables are not related. This implies that the performance of employees, mainly, does not change as the years go by (McEvoy \& Cascio, 1989). Another metaanalysis revealed that as age progresses there are no significant changes in task performance and creativity $(\mathrm{Ng} \&$ Feldman, 2008). For example, in a computer task, old adults did not reveal differences compared with young and middle-aged adults at the level of the quality of the work that they performed, but the quantitative aspect was less than those of other ages (Czaja \& Sharit, 1998). One study that investigated employee performance in two types of professional activity, clerical and craft jobs (with two degrees of complexity each), revealed that there is no correlation between performance and age, or just modest correlations for certain types of professional activities (Avolio, Waldman \& McDaniel, 1990).

In contrast with the studies mentioned above, there is also evidence in favour of a relationship between performance and age in the form of an inverse U. This means that up to the age of 49 years performance gradually increases, yet from this point performance progressively decreases as employees become older (Sturman, 2003). But there is also evidence that indicates that certain types of performance even grow with age advancement. In this sense the meta-analysis of $\mathrm{Ng}$ and Feldman (2008) revealed that older employees present more citizenship behaviours, are more inclined to avoid counterproductive behaviours, are more responsible, more punctual, more careful with work attendance, and are less likely to engage in substance consumption behaviours.

Therefore, despite the fact that, at the social level, there is a concern about the lack of competence of older workers, the above research data reveals that this concern is exaggerated. Professional performance in some sectors is identical, in other sectors it is modestly smaller, while in other sectors it is even better than the other ages (Posthuma \& Campion, 2009; Erber \& Szuchman, 2015).

\section{Older employees' abilities}

In order to deepen the performance aspects, different types of job demands should also be considered, taking into account, also, the dynamics of different abilities and age-specific characteristics. Although the definition of an old employee is vague (Phillips \& Siu, 2012), it can be roughly revealed which abilities that are in a negative correlation with age and could lead to some differences in performance, in different job related tasks. Job related tasks that require intense physical strength may be difficult for some older employees, making their performance lower than at the other ages, due to the fact muscle strength starts to decrease with age (Metter, Conwit, Tobin \& Fozard, 1997; World Health Organization, 1998). Therefore, tasks that involve, for example, carrying of highweight products, tasks that involve moving 
heavy objects, or frequent lifting, may be done with difficulty by older employees compared with younger employees. Resistance to intense physical effort also decreases with advancing age (Power, Dalton \& Rice 2013), which may lead to a decreased performance in job activities that require intense physical effort for many hours, such as mining activities. Speed may decrease too, but except in situations where physical demands are intense, and where physical demands are often moderate, experience can offset these slowdowns (Bowen, Noack \& Staudinger, 2011; Erber, 2013). Jobs with tasks that involve intense physical demands are not among the fastest growing jobs either today or in the future; jobs in great demand today are those that involve cognitive skills more than intense physical activity (Albright, 2012; Holmes \& Mahyew, 2012). Cognitive abilities, on the other hand do not decrease at the same rate. Many people in their 60 s or early $70 \mathrm{~s}$ do not show a significant decrease in cognitive abilities (Schaie, 1994; Schaie \& Willis, 2010;). Some of them even show some an increase at advanced ages. For example, semantic memory (knowledge) evidences an increase in performance in the $60 \mathrm{~s}$, and a decrease after ones 70s (Nyberg et al., 2003). Those cognitive abilities that evidence a relatively small decrease for adults in their 60 s and early 70 s are related with: working memory (Belleville, Peretz \& Malenfant, 1996); episodic memory (Bender, Naveh-Benjamin \& Raz, 2010); cognitive processing speed (Bashore, Ridderinckof \& van der Molen, 1997) and so on.

Even if older employees may experience some slowdown in cognitive ability, it seems that experience makes these slowdowns barely visible at the level of professional performance for older workers (Bowen et al., 2011; Erber, 2013). Experience, staying cognitively active, exercising, working with certain tasks / contents, can have a protective effect, maintaining cognitive performance (Schaie, 1994; Schaie, 2005). Employees who have had a complex career path demonstrate higher levels of cognitive abilities and cognitive performance at old age (Smart, Gow \& Deary, 2014).

\section{Implications of social stereotyping about older adults' competence}

The fact that society portrays older employees' competence and performance in a negative way, has multiple implications. The effects of such a negative portrayal are observed in the level of performance. Studies have revealed that when older adults know that poor performance is expected of them (negative social stereotyping), there is a higher probability that they will perform poorly compared with a situation in which they are not exposed to such negative expectations on the part of others (Hess, Auman, Colcombe, \& Rahhal, 2003; Haslam et al., 2012; Swift, Lamont, \& Abrams, 2012). The negative implications are more visible in terms of cognitive activities; when older adults come into contact with negative stereotypes about cognitive performance at advanced ages, they underperform in cognitive tasks compared with adults who do not came into contact with such negative stereotypes (Lamont, Swift, \& Abrams, 2015). The implications of this phenomenon, agebased stereotype threat (underperformance when coming in contact with negative stereotype about old age), are major, certainly at the organizational level, but also socially and emotionally.

\section{Conclusions}

As a result, society's concerns about the capabilities of older employees are not wholly justified. Older employees can be an important resource for organizations in the context of an aging world. 


\section{REFERENCES}

Abrams, D., Vauclair, M. \& Swift, H. (2011). Predictors of attitudes towards age in Europe, Research Report No. 735, available at: https://assets.publishing.service.gov.uk, accessed on: 10 September 2018

Age UK. (2005). How ageist is Britain?. London: Age Concern.

Albright, V. A. (2012). Workforce demographics in the United states: Ocupational trends, work rates, and retirement projections in the United States. In J. W. Hedge \& W. W. C. Borman (Eds.), The oxford handbook of work and aging, 11-32. New York: Oxford University Press.

Avolio, B. J., Waldman, D. A., \& McDaniel, M. A. (1990). Age and work performance in non-managerial jobs: The effects of experience and occupational type. Academy of Management Journal, 33, 407-422.

Bashore, T. R., Ridderinckof, K. R., \& van der Molen, M. W. (1997). The decline of cognitive processing speed in older ages. Current Directions in Psychology Sciences, 6(6), 163-169.

Belleville, S., Peretz, I., \& Malenfant, D. (1996). Examination of the working memory components in normal aging and in dementia of the Alzheimer type. Neuropsychologia, 34, 195-207.

Bender, A. R., Naveh-Benjamin, M., \& Raz, N. (2010). Associative deficit in recognition memory in a lifespan sample of healthy adults. Psychology and Ageing, 25(4), 940-948.

Bowen, C. E., Noack, M. G. \& Staudinger, U. M. (2011). Aging in the work context. In Schaie, K. W., \& Willis, S. L. (Eds.) Handbook of the psychology of aging, $7^{\text {th }}$ ed., 263-277, San Diego: Elsevier Academic Press.

Czaja, S. J., \& Sharit, J. (1998). Ability-performance relationships as a function of age and task experience for a data entry task. Journal of Experimental Psychology: Applied, 4(4), 332-351.

Erber, J. T. (2013). Aging \& older adulthood. West Sussex, UK: Wiley Blacwell.

Erber, J. T., \& Szuchman, L. T. (2015). Great myths of aging. West Sussex, UK: Wiley Blacwell.

Gordon, R. A., \& Arvey, R. D. (2004). Age bias in laboratory and field settings: A meta-analytic investigation. Journal of Applied Psychology, 34, 468-492.

Haslam, C. et al. (2012). When the age is in, the wit is out: Age-related categorization and deficit expectations reduce performance on clinical tests used in dementia assessment. Psychology and Aging, 27, 778-784.

Hess, T. M., Auman, C., Colcombe, S. J., \& Rahhal, T. A. (2003). The impact of stereotype threat on age differences in memory performance. The Journals of Gerontology: Series B: Psychological Sciences and Social Sciences, 58, 3-11.

Holmes, C. \& Mahyew, K. (2012). The changing shape of the UK job market and its implications for the bottom half of earners, available at: http://www.resolutionfoundation.org/ app/uploads/2014/08/The-Changing-Shape-of-the-UK-Job-Market.pdf, accessed on: 10 September 2018

Kontis, V. et al. (2017). Future life expectancy in 35 industrialised countries: projections with a Bayesian model ensemble. Lancet, 389, 1323-1335.

Lamont, R. A., Swift, H., J., \& Abrams, D. (2015). Review and meta-analysis of agebased stereotype threat: Negative stereotypes, not facts, do the damage. Psychology and Aging, 30(1), 180-193. 
McEvoy, G. M., \& Cascio, W. F. (1989). Cumulative evidence of the relationship between employee age and job performance. Journal of Applied Psychology, 74, 11-17.

Nyberg, L. et al. (2003). Selective adult age differences in an age-invariant multifactor model of declarative memory. Psychology and Aging, 18, 149-160.

Ng, T. W. H., \& Feldman, D. C. (2008). The relationship of age to ten dimensions of job performance. Journal of Applied Psychology, 93(2), 392-423.

Phillips, D. R. \& Siu, O. (2012). Global aging and aging workers. In J. W. Hedge \& WW. C. Borman (Eds.). The oxford handbook of work and aging, 11-32. New York, NY: Oxford University Press.

Posthuma, R. A., \& Campion, M. A. (2009). Age stereotypes in the workplace: Common stereotypes, moderators, and future research directions. Journal of Management, 35(1), 158-188.

Power, G. A., Dalton, B. H., \& Ric, C. L. (2013). Human neuromuscular structure and function in old age: A brief review. Journal of Sport and Health Science, 2, 215-226.

Schaie, K. W. (1994). The course of adult intellectual development. American Psychologist, 49, 304-313.

Schaie, K. W., \& Willis, S. L. (2010). The Seattle Longitudinal Study of adult cognitive development. ISSBD Bulletin, 1(57), 1-10.

Smart, E. L., Gow, A. J., \& Deary, I. J. (2014). Occupational complexity and lifetime cognitive abilities. Neurology, 83(24), 2285-2291.

Sturman, M. C. (2003). Searching for the inverted U-shaped relationship between time and performance: Meta-analyses of the experience/performance, tenure/performance, and age/performance relationships. Journal of Management, 29, 609-640.

Swift H. J., Lamont, R. A., \& Abrams, D. (2012). Are they half as strong as they used to be? An experiment testing whether age-related social comparisons impair older people's hand grip strength and persistence. BMJ Open, 2, 1-6.

United Nations, Department of Economic and Social Affairs, Population Division (2013). World Population Ageing 2013. (ST/ESA/SER.A/348), available at: http://www.un.org/ en/development/desa/population/publications/pdf/ageing/WorldPopulationAgeing2013.pdf, accessed on: 01 September 2018.

United Nations, Department of Economic and Social Affairs, Population Division (2017a). World Population Ageing 2017 - Highlights (ST/ESA/SER.A/397), available at: http://www.un.org/en/development/desa/population/publications/pdf/ageing/WPA2017_Highl ights.pdf, accessed on: 01 September 2018.

United Nations, Department of Economic and Social Affairs, Population Division (2017b). World Population Prospects: The 2017 Revision, Key Findings and Advance Tables. Working Paper No. ESA/P/WP/248, available at: https://esa.un.org/unpd/wpp/ Publications/Files/WPP2017_KeyFindings.pdf, accessed on 01 September 2018.

World Health Organization (1998). Growing older - staying well. Ageing and physical activity in everyday life, available at: http://apps.who.int/iris/bitstream/10665/ 65230/1/WHO HPR AHE 98.1.pdf, accessed on: 06 July 2016. 